\title{
An exploration of the effects of pandemic influenza on infant mortality in Toronto, 1917-1921
}

\author{
Stacey Hallman \\ Department of Sociology, University of Western Ontario \\ shallma@uwo.ca
}

\begin{abstract}
This study investigates infant mortality from pandemic influenza in Toronto, Canada, from September to December 1918, through the Registered Death Records of the Province of Ontario. A comparison of infant deaths in 1918 to surrounding years (1917-21) revealed that although mortality rates remained relatively stable, there were changes in the mortality profile during the epidemic. Deaths from influenza did increase slightly, and the epidemic altered the expected sex ratio of infant deaths. Although communities may be greatly strained by an influenza epidemic, the infant mortality rate may be more representative of long-term social and environmental conditions rather than acute, intensive crises.
\end{abstract}

Keywords: historical demography, historical epidemics, influenza, infant mortality.

\section{Résumé}

Cette étude porte sur la mortalité infantile résultant d'une pandémie d'influenza qui a eu lieu à Toronto (Canada) de septembre à décembre 1918, à partir des enregistrements de décès des dossiers de l'état civil de l'Ontario. La comparaison des morts infantiles en 1918 et celles qui ont eu lieu entre 1917 et 1921 révèle que les taux de mortalité sont demeurés relativement stables, mais que le profil de mortalité a changé pendant l'épidémie. Le nombre de décès causépar l'influenza a augmenté légèrement et l'épidémie a modifié le rapport de masculinité des morts infantiles. Bien que les communautés soient très éprouvées par une épidémie d'infuenza, le taux de mortalité infantile peut davantage refléter les conditions sociales et environnementales à long terme que les crises aiguës intensives.

Mots-clés : démographie bistorique, épidémies historiques, influenza, mortalité infantile.

\section{Introduction}

The influenza epidemic of 1918 represented a period of crisis mortality in Ontario and around the world (Bouckaert 1989). This epidemic is noted for its unusual mortality profile. Although those most often the victims of infectious diseases (infants and the elderly) were also affected by the epidemic, a striking anomaly in the pattern of death occurred in the increased mortality of young adults between 20 and 40 years old (Toronto Archives, Fonds 200, Series 365, File 21; Harder 1918; Crosby 1976; Pettigrew 1983; Taubenberger 2003). This pattern has been variously attributed to the particular pathology of the disease, but also to the global environment in 1918 (Lancet 1918; Taubenberger et al 2000; Oxford et al. 2002; García-Sastre and Whitley 2006). At the close of the First World War, many young people were travelling around the world to fields of battle, and home again to their families. These young men and women had thus been exposed to many people from around the world, which opened a pathway for the spread of infections. Further, many soldiers were weakened from the unhealthy conditions of the war-injuries, psychological trauma, and diseases such as tuberculosis. The families to whom they returned were similarly stressed from years of war-time rationing and the distress of war-time events; as recognized by Handwerker, "virtually any demographic change thus alters both the physical and mental health of a community" (1990: 320; Lancet 1918). 
Research on the 1918 influenza is slowly increasing, although few studies are dedicated to the Canadian situation (Pettigrew 1983; Herring 1993; Sattenspiel and Herring 1998, 2003; Herring 2005 for Hamilton; Jones 2005; Herring and Sattenspiel 2007; MacDougall 2007; and Jones 2007 for Winnipeg). Contemporary articles in the Journal of the Canadian Medical Association and later ones from the Canadian Public Health Journal briefly describe the situation in Toronto and Montreal, focusing mainly on the outbreaks of influenza among soldiers, the symptoms of the disease, and the debate over the identification of the disease as influenza and the role of Pfeiffer's bacillus, Bacillus influenzae (re-named Haemophilus infuenzae; Boucher 1918; CMAJ 1918; McCullough 1918; Oertel 1919; Robertson 1919; Young 1919; Hare 1937). More recent research addresses the Canadian situation intermixed with global accounts (Collier 1974; Crosby 1989), or mentions the flu only in passing while addressing other topics (MacDougall 1990; Miller 2002).

The flu first came to Toronto during the second wave of the global pandemic (the three waves occurred in the spring of 1918, the fall of 1918, and the winter-spring of 1919). It "officially" hit the city on October 3, 1918 (The Globe 1918a; Pettigrew 1983: 48), and the Monthly Reports of the Department of Public Health reveals that 1084 people died from influenza or pneumonia in October (Toronto Archives, Fonds 200, Series 365, File 21). Although it peaked in late October, the epidemic continued throughout the rest of 1918 and over the next few years (The Globe 1918e; Crosby 1989). The Department of Health recorded that a total of 3,118 people died from influenza and pneumonia in Toronto in 1918 (Toronto Archives, Fonds 200, Series 365, File 21) and Miller estimates that up to half of the city (over 260,000 people), was infected in October (Miller 1999). Pettigrew believes that for the entire epidemic, Ontario had 300,000 people sick with the flu, of which 8,705 died (1983: 56).

Rosenberg explains that "since at least the eighteenth century, physicians and social commentators have used the difference between 'normal' and extraordinary levels of sickness as an implicit indictment of pathogenic environmental circumstances" (1989: 12). The 1918 influenza pandemic fits this criterion, since in Toronto alone, over half of the city had the flu in October 1918 (Miller 2002). Globally, between 40 and 100 million people died (Johnson 2003). Yet, as known from contemporary sources, this epidemic did not strike the population equally (The Globe 1918c, 1918d; Harder 1918; Winternitz et al. 1920). The aggregate published data, however, give no impression of how social, environmental, and biological factors may have influenced risk of death.

Analysis of the mortality of infants in Toronto during this epidemic is a novel means to approach the situation in Canada in 1918. This approach addresses the question that Nancy Scheper-Hughes believes should be asked of all critically interpretive research (1997: 220): "What is being hidden from view in the official statistics?" Although her appeal is to contemporary anthropological demographers, this research examines information that is masked in the official reports of the $1918 \mathrm{flu}$ in Toronto. By describing the historical as well as biomedical background of the epidemic, and suggesting further research into structural inequalities, this research is placed in a perspective that focuses on "historically specific social forces, relations, and processes surrounding sickness and health care" (1990). This is accomplished by investigating hypotheses of equal rates of infection and death within the historically bounded context of early twentieth-century Toronto.

Infant mortality is represented in a rate as the number of deaths per 1,000 live births (Mausner and Bahn 1974). It is divided into neonatal and postneonatal age categories, due to the different causation of death at different ages. The neonatal age group represents infants who died in the first 28 days of life $(<28$ days $)$ and deaths are generally thought to be caused by "endogenous" biological causes such as "perinatal infections, congenital malformations, and maternal conditions" (Matteson et al 1998: 1845). Infants who died between the ages of 29 days and 365 days are classified as postneonatal deaths, and are generally caused by "exogenous" environmental causes, such as "most types of infections, nutritional deficiencies, SIDS, violence, and other external causes" (Matteson et al 1998: 1845). Although there is some overlap between endogenous and exogenous causes and age at death, generally deaths resulting from the conditions of pregnancy cluster in the first month of life (Knodel 1988; Matteson et al. 1998). During the 1918 influenza, epidemic-related neonatal deaths were likely caused by maternal infection with influenza that affected the developing fetus, pre-term labour, or resulted from maternal-death related starvation. Post-neonatal deaths due to the epidemic can include the effects of maternal infection, but were more likely to have resulted from direct infection with influenza, and environmental degradation caused by the death or illness of the primary care-givers. According to Knodel (1988), seasonal variation in the patterning of deaths is a product of fluctuating post-neonatal infant mortality, because neonatal infant mortality remains somewhat stable throughout the year. 
Hallman: An exploration of the effects of pandemic influenza on infant mortality in Toronto, 1917-1921

To determine the pattern of infant mortality in Toronto from 1917 to 1921 and ascertain whether the 1918 influenza epidemic affected it in any way, five different aspects of infant death were investigated. First, the overall infant mortality rate was considered, both yearly and monthly, to determine the death rates. Then the sex ratio at death was examined to see if the influenza epidemic targeted one sex over the other. The average age at death is studied for the same reason: to discover if either neonatal ( $<1$ month) or postneonatal ( $\geq 1$ month) infants were at higher risk. Finally, causes of death are investigated to determine whether influenza did affect infants and to find out if deaths from other causes decreased during the epidemic.

\section{Location and socioeconomic context}

This paper concerns infant mortality in Toronto, the capital city of the province of Ontario, Canada. Social inequalities were a significant aspect of life in the city during the early part of the twentieth century. As the largest city in Ontario and a centre for immigration, Toronto saw its population grow from approximately 200,000 in 1900 to 470,000 in 1915, and to 540,000 by 1924 (Department of Health 1917, 1924). As seen through the records and concerns of the Department of Health (1917-24), Toronto experienced many of the problems of a city trying to accommodate rapid expansion and immigration. The city, especially the slums such as the Ward (Mercier 2006), was crowded, with high rents and inadequate housing (Solomon 2007: 17-22).

In 1901, Toronto was a "relatively unhealthy" city in terms of its infant mortality, at 167 deaths per 1,000 live births (Mercier 2006: 127). Mercier portrays 1901 Toronto as a place highly segregated by neighbourhood and stratified by class and culture (Mercier 2006). These inequalities were reflected in infant mortality rates throughout the city. In his analysis of the location of infant and child death, crowding in houses, socioeconomic status, and culture in Toronto, Mercier found that, while all forms of lower socioeconomic status increased infant and child mortality, the greatest variation in the rate of death resulted from religious and cultural differences. However, Mercier affirms that neighbourhood-based differences do not explain all the variation in infant mortality because of "complex interaction effects" (2006: 146).

In 1911, the city was still plagued by socioeconomic inequalities, which continue to this day. Dr. Hastings (the Medical Officer of Health) reported that the Ward, Corktown, and Niagara neighbourhoods were slums, and that "privies and cesspools, shack-housing, and extreme poverty and crowding predominated in these areas" (Mercier 2006: 131-2). When the city was faced with the depression of 1913-15 (MacDougall 1990), followed by the restrictions and inflation resulting from World War I, it seems unlikely that underlying and persistent variations in health status and access to resources would have translated into an equal experience of infectious and epidemic disease.

\section{Materials and methods}

This research was conducted using the Registered Death Records of the Province of Ontario, currently publicly available on microfilm at the Archives of Ontario in Toronto. ${ }^{1}$ The Registrar General of the Province of Ontario documented 8,952 records of infant death from the period 1917-21. These records contained information on the deaths of 9,017 stillborn and live-born infants (Table 1). ${ }^{2}$ As noted by Emery (1993), by 1917 the death records in Ontario were almost complete, making the materials of this study (the Registered Deaths of the Province of Ontario) a suitable means to attempt a description of infant mortality in the city. Data on total population and total numbers of live and stillbirths from 1917-21 were found in the Sessional Papers of the Legislative Assembly of the Province of Ontario, also located on microfilm at the Archives of Ontario (Table 2).

The majority of the infant death records from 1917-21 were transcribed at the archives. The remainder were transcribed from JPEG copies of the death records previously created by Karen Slonim (Department of Anthropology, University of Missouri) and made available for this project. Death records from 1917 were collected in order to establish a pre-epidemic baseline that includes yearly seasonal fluctuations in infant mortality from which to compare the epidemic mortality of the waves of influenza (Spring 1918, September to December 1918, Winter 1919, and the return in 1920). The infant death records for 1921 were transcribed in order to determine if there were lingering effects of the epidemic on infant mortality, and to enable a five-year study of infant death.

1. Archives of Ontario MS 935, Reels 228-9, 238-40, 251-2, 261-2, 273-4.

2. The discrepancy between the number of records and the number of individuals represented by those records results from twins who died at the same time (often stillborn or in the perinatal period) being recorded on the same record. 
Table 1. Total individuals represented in the death registrations of the province of Ontario for the city of Toronto, divided into age-at-death and sex and total births per year by sex (Legislative Assembly of the Province of Ontario, 1918-22)

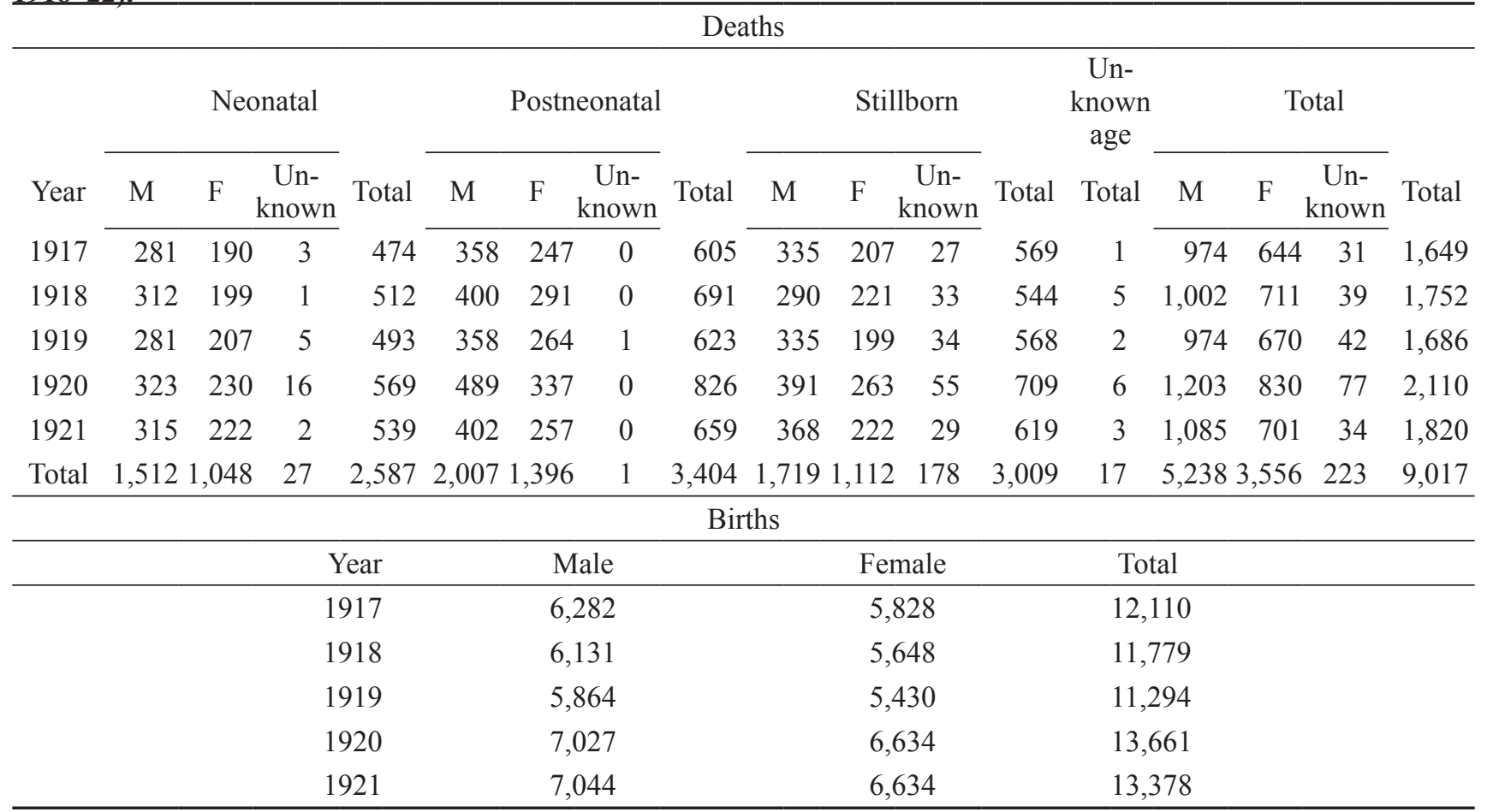

\section{Results}

The infant mortality rate for Toronto from 1917 to 1921, as calculated from the 6,008 Registered Deaths of the Province of Ontario for this period, can be seen in Figure 1 as a three-month moving average for total infant mortality, neonatal, and postneonatal infant mortality rates. The overall infant mortality rates for each year are presented in Table 2.

The average infant mortality rate for Toronto for the five-year period was 96.91 deaths per 1,000 live births $(\mathrm{N}=6,008)$. The lowest infant mortality rate recorded over the five-year period was in June 1921 at 61.26 deaths per $1,000$ live births ( $\mathrm{n}=71)$. The highest rate occurred in October 1918, at 147.84 deaths per 1,000 live births $(\mathrm{n}=144)$. Figure 1 suggests a seasonal pattern for infant mortality. For each year, the highest infant mortality rate was found between August and October, with annual peaks noted for September 1917 (114.34 deaths per 1,000 live births, $\mathrm{n}=114$ ), October 1918 (147.84 deaths per 1,000 live births, $\mathrm{n}=144$ ), August 1919 (121.54 deaths per 1,000 live births, $\mathrm{n}=101$ ), October 1920 (135.78 deaths per 1,000 live births, $n=137$ ), and September 1921 (137.33 deaths per 1,000 live births, $\mathrm{n}=149$ ). While the month with the lowest infant mortality rate varied each year, infant mortality consistently dropped during the summer months of June and July.

Table 2. Annual infant mortality rates, neonatal and postneonatal, Toronto, 1917-21, calculated from the registered deaths of the province of Ontario and the Sessional Papers of the Legislative Assembly of Ontario (Archives of Ontario MS 935 and Series B 97).

\begin{tabular}{crcc}
\hline Year & Infant Mortality Rate & Neonatal Mortality Rate & Postneonatal Mortality Rate \\
\hline 1917 & $89.18(\mathrm{n}=1,080)$ & $39.14(\mathrm{n}=474)$ & $49.96(\mathrm{n}=605)$ \\
1918 & $102.56(\mathrm{n}=1,208)$ & $43.47(\mathrm{n}=512)$ & $58.66(\mathrm{n}=691)$ \\
1919 & $98.99(\mathrm{n}=1,118)$ & $43.65(\mathrm{n}=493)$ & $55.16(\mathrm{n}=623)$ \\
1920 & $102.55(\mathrm{n}=1,401)$ & $41.65(\mathrm{n}=569)$ & $60.26(\mathrm{n}=826)$ \\
1921 & $89.77(\mathrm{n}=1,201)$ & $40.29(\mathrm{n}=539)$ & $49.26(\mathrm{n}=659)$ \\
\hline TOTAL & $96.91(\mathrm{n}=6,008)$ & $41.66(\mathrm{n}=2,587)$ & $54.98(\mathrm{n}=3,404)$ \\
\hline
\end{tabular}

Mortality rates given in deaths per 1,000 live births. 


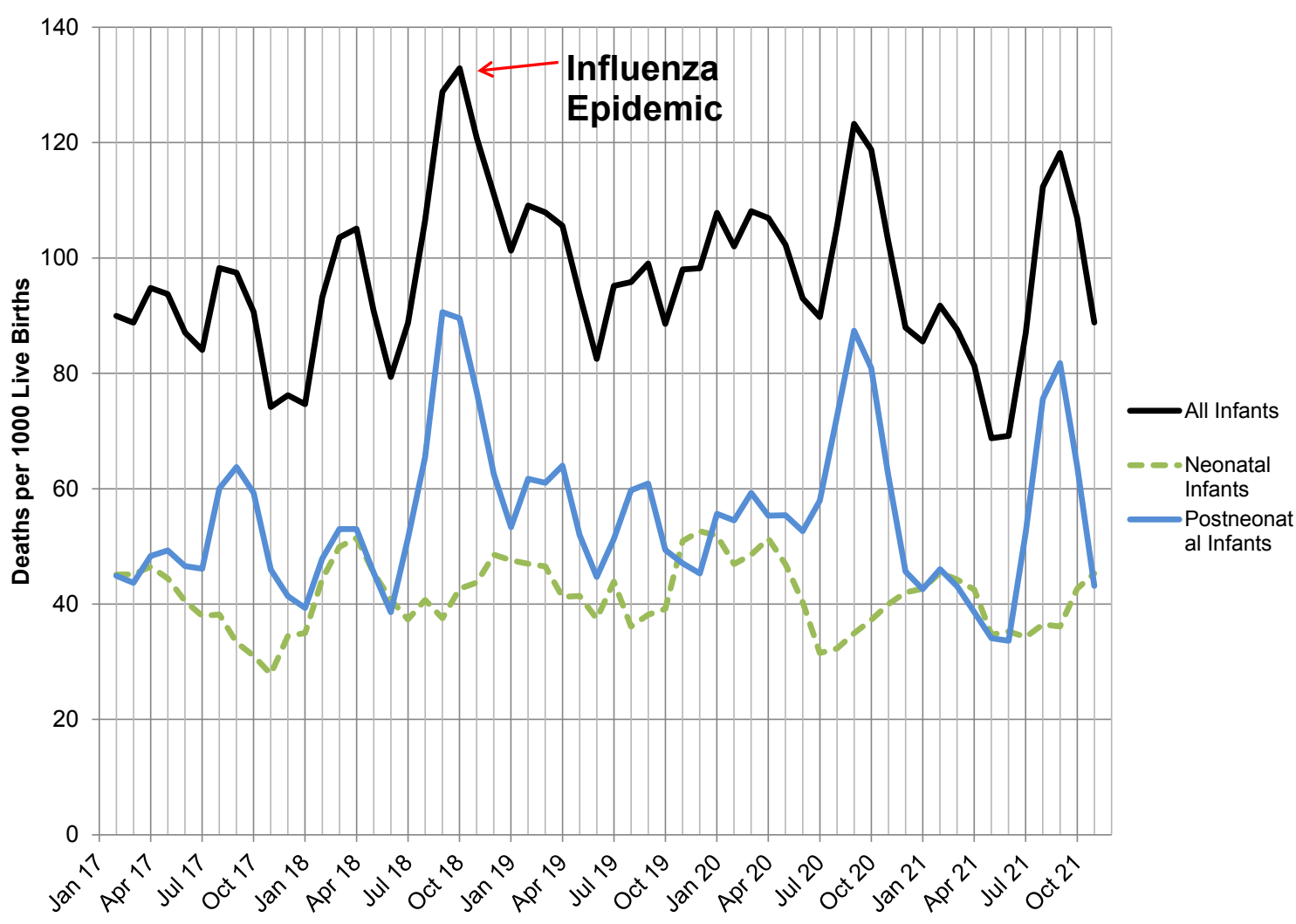

Figure 1. Total infant mortality rate, postneonatal mortality rate, and neonatal mortality rate, 1917-21: Three-month moving average.

The second wave of the influenza epidemic in October 1918 was associated with the highest infant mortality rate over the five year period (147.84 deaths per 1,000 live births), but large increases in infant mortality also occurred in October 1920 (135.78 deaths per 1,000 live births) and in September 1921 (137.33 deaths per 1,000 live births). There was no significant differences in the annual rates of infant death over the five year period (1917 vs. 1918 vs. 1919 vs. 1920 vs. 1921) ( $\mathrm{p}=.238)$.

In 2000, the sex ratio at birth of males to females in Canada was 1,056 males to 1,000 females, or 1.06:1 (Mathews and Hamilton 2005: 5). Table 3 presents the sex ratio at birth and the sex ratio at death for Toronto for the five-year study period. The sex ratio at birth was calculated using the total births found in the Sessional Papers of the Legislative Assembly of Ontario (Legislative Assembly of Ontario 1918-1922). The sex ratio at death was calculated from the death registrations.

Table 3. Live birth male-to-female sex ratios and sex ratios at death, Toronto, 1917-21.

\begin{tabular}{ccc}
\hline Year & $\begin{array}{c}\text { Sex Ratio at Birth } \\
(\text { M:F) }\end{array}$ & $\begin{array}{c}\text { Sex Ratio at Death } \\
(M: F)\end{array}$ \\
\hline 1917 & $1.08: 1(\mathrm{n}=12,110)$ & $1.36: 1(\mathrm{n}=1,080)$ \\
1918 & $1.09: 1(\mathrm{n}=11,779)$ & $1.32: 1(\mathrm{n}=1,208)$ \\
1919 & $1.08: 1(\mathrm{n}=11,294)$ & $1.26: 1(\mathrm{n}=1,118)$ \\
1920 & $1.06: 1(\mathrm{n}=13,661)$ & $1.34: 1(\mathrm{n}=1,401)$ \\
1921 & $1.11: 1(\mathrm{n}=13,378)$ & $1.35: 1(\mathrm{n}=1,201)$ \\
\hline
\end{tabular}

As can be seen from the male-to female sex ratios at death, there was a general selection bias towards males over the five-year period 1917-21. This is to be expected, given the generally higher male death rate at all ages of life, and in light of factors influencing infants specifically, such as the stronger female immune system and the higher proportion of male infants born pre-term (Drevenstedt et al. 2008). Further, the Canada-wide average sex ratio at death from 1921-5 was found to be 126 males to every 100 females, ranging from 122 to 128 males per females (for eight 
reporting provinces; MacPhail 1927). The average ratio for Toronto for the five-year period was 1.38 male deaths for every one female death $(n=5,980)$, ranging from a low of 0.8:1 in October $1919(\mathrm{n}=96)$ to a high of 2.35:1 in March 1917 ( $n=83$ ). Although somewhat higher than the later Canadian average, the Toronto figures represent a slightly earlier time period (in a context of improving mortality) and an urban population, while the Canadian figures combine both rural and urban. Urban populations had higher rates of infant mortality generally, which could be driving these figures upwards (Williams and Galley 2005). The Toronto sex ratios at death during the five-year period therefore appear to be consistent with the Canadian average.

The month that recorded the highest male-to-female mortality ratio varied over the five years. ${ }^{3}$ However, interestingly, the lowest male-to-female ratio at death was more consistent, occurring in October in three of the five years. For two of those years (1918 and 1919) more females died in October than males. ${ }^{4}$ The differences between years was not significant $(\mathrm{p}=.895)$, but the monthly variation of sex ratios at death was significant $(\mathrm{p}=.042)$. However, when October 1918 and 1919 were removed from the analysis, the monthly variation in the sex ratio at death was not significant $(\mathrm{p}=.163)$. This indicates that the 1918 influenza epidemic altered the normal patterning of the sex ratio at death by increasing the number of females who died in October compared to males.

Separating the total infant mortality rate into neonatal and postneonatal infant deaths does not add to the understanding of the sex ratio at death patterns. Both the neonatal and postneonatal infant mortality varied throughout the months, and generally followed the pattern of total sex ratio at death. No significant differences were found when either was compared by year or by month. However, it is interesting to note that similar ratios were found among neonatal and postneonatal infants during October 1918, the worst month of the epidemic. Specifically, among infants of all ages, more females died than males during this month (Fig. 2, Table 4).

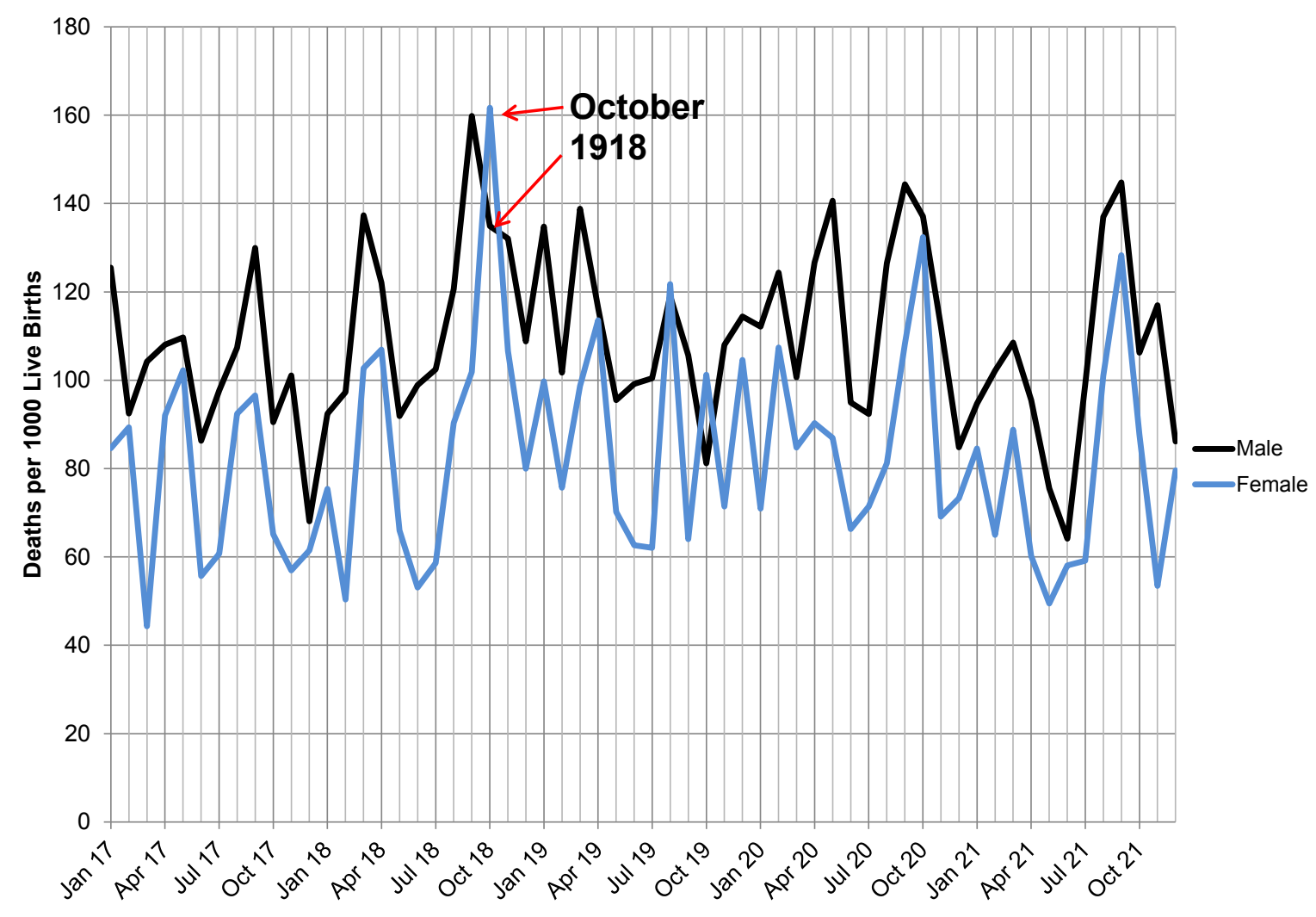

Figure 2. Male and female infant mortality rates, 1917-21.

3. 1917: March, 2.35:1 ( $\mathrm{n}=83) ; 1918$ : February, 1.93:1 ( $\mathrm{n}=69) ; 1919:$ September, 1.65:1 ( $\mathrm{n}=88) ; 1920:$ May and November, 1.62:1 ( $\mathrm{n}=136,87) ; 1921:$ November, 2.19:1 ( $\mathrm{n}=89)$.

4. 1917: February, 1.04:1 ( $\mathrm{n}=89) ; 1918:$ October, 0.83:1 ( $\mathrm{n}=144) ; 1919:$ October, 0.8:1 ( $\mathrm{n}=96) ; 1920:$ October, 1.04:1 ( $\mathrm{n}=136) ; 1921$ : December, 1.08:1 ( $\mathrm{n}=85)$. Except for August 1919 (ratio=0.98, $\mathrm{n}=101)$, October 1918 and October 1919 were the only months in which more females died than males. 
Hallman: An exploration of the effects of pandemic influenza on infant mortality in Toronto, 1917-1921

Table 4. Infant sex ratios at death, epidemic period: September to December, 1918.

\begin{tabular}{cccc}
\hline Month $(1918)$ & Neonatal Infants & Postneonatal Infants & All Infants \\
\hline September & $1.17: 1(\mathrm{n}=45)$ & $1.93: 1(\mathrm{n}=80)$ & $1.63: 1(\mathrm{n}=126)$ \\
October & $0.82: 1(\mathrm{n}=32)$ & $0.85: 1(\mathrm{n}=111)$ & $0.89: 1(\mathrm{n}=144)$ \\
November & $1.20: 1(\mathrm{n}=39)$ & $1.26: 1(\mathrm{n}=59)$ & $1.33: 1(\mathrm{n}=98)$ \\
December & $1.66: 1(\mathrm{n}=80)$ & $1.09: 1(\mathrm{n}=41)$ & $1.44: 1(\mathrm{n}=88)$ \\
\hline
\end{tabular}

The male-to-female sex ratios at death for Toronto did not alter greatly throughout the five year period 1917-21, and although slightly higher (1.38:1) were generally comparable to ratios for Canada as a whole for the subsequent five-year period (1:26:1), reported by MacPhail (1927).

\section{Infectious causes of death}

To explore the infectious causes of death in more detail, three categories were utilized: airborne diseases, food and waterborne diseases, and all other infectious causes of death. ${ }^{5}$ The average infant mortality rate for the five-year period due to airborne infectious diseases was 20.85 deaths per 1,000 live births $(n=1,296),{ }^{6}$ with a low of 3.98 deaths per 1,000 live births in October $1921(\mathrm{n}=4)$, to a high of 62.63 deaths per 1,000 live births in October $1918(\mathrm{n}=61)$. This variation was not significant according to a one-way ANOVA test ( $p=.167$, Welch: $p=.155$ ). The average infant mortality rate for the five-year period due to food and waterborne infectious diseases was 12.21 deaths per 1,000 live births $(\mathrm{n}=758$,), ranging from a low of 0.95 deaths per 1,000 live births in May $1918(\mathrm{n}=1)$ to a high of 58.06 deaths per 1,000 live births in September $1921(\mathrm{n}=63)$. The yearly variation in food and waterborne illnesses was not significant $(\mathrm{p}=.894)$.

Generally, there is an inverse relationship between deaths from airborne infectious diseases and food and waterborne infectious diseases. When there is an increase in deaths from food and waterborne illnesses there is a concomitant decline in deaths from airborne infectious diseases. This reflects the seasonal variability of these diseases, as deaths from diarrheal diseases (transmitted through food and water) generally increase during the summer months, while deaths from airborne diseases generally increase in winter (Collins and Lehmann 1951; Thomas et al. 2006; Lofgren et al. 2007). Deaths from food and waterborne diseases increase in August of each year, and continue to be high until September or October. The months with the most deaths per year from both food and waterborne infectious diseases and airborne illness are shown in Table 5. The highest death rate for food and waterborne illness over the entire five-year period was recorded in September 1921, mostly from diarrhea and fermentative diarrhea. The monthly variation in food and waterborne illnesses is significant $(\mathrm{p}<.001)$.

Table 5. Month with most deaths from food and waterborne infections and airborne diseases.

\begin{tabular}{ccc}
\hline Year & $\begin{array}{c}\text { Month of most deaths due to food and } \\
\text { waterborne causes (rate per 1,000 live births) }\end{array}$ & $\begin{array}{c}\text { Month of most deaths due to airborne causes } \\
\text { (rate per 1,000 live births) }\end{array}$ \\
\hline 1917 & September: $35.11(\mathrm{n}=35)$ & April: $31.58(\mathrm{n}=33)$ \\
1918 & September: $45.41(\mathrm{n}=44)$ & March:44.26 $(\mathrm{n}=47)$ \\
1919 & August: $30.08(\mathrm{n}=32)$ & March: $43.95(\mathrm{n}=45)$ \\
1920 & October: $31.71(\mathrm{n}=32)$ & February: $56.87(\mathrm{n}=65)$ \\
1921 & September: $58.06(\mathrm{n}=63)$ & March: $33.52(\mathrm{n}=42)$ \\
\hline
\end{tabular}

5. The infectious causes of death were divided in this manner as per McKeown (1976), Moffat (1992), Gray (1997) and based on the causes of disease in the Forty-Fourth Annual Report of the Hospital for Sick Children in Toronto (1919), and the International Statistical Classification of Diseases and Related Health Problems, 10th Revision Version for 2007 (ICD-10 v. 2007; WHO 2007). The analysis was conducted following Padiak (2004).

6. These results must be interpreted with caution due to the low sample sizes. The range of infant deaths due to airborne infectious diseases spans a low of 4 deaths in October 1921 to a high of 65 in February 1920. Likewise, the total number of infant deaths due to food and waterborne causes ranged from a low of 1 death in May 1918, February 1919, and December 1920 to a high of 64 deaths in August 1921. 


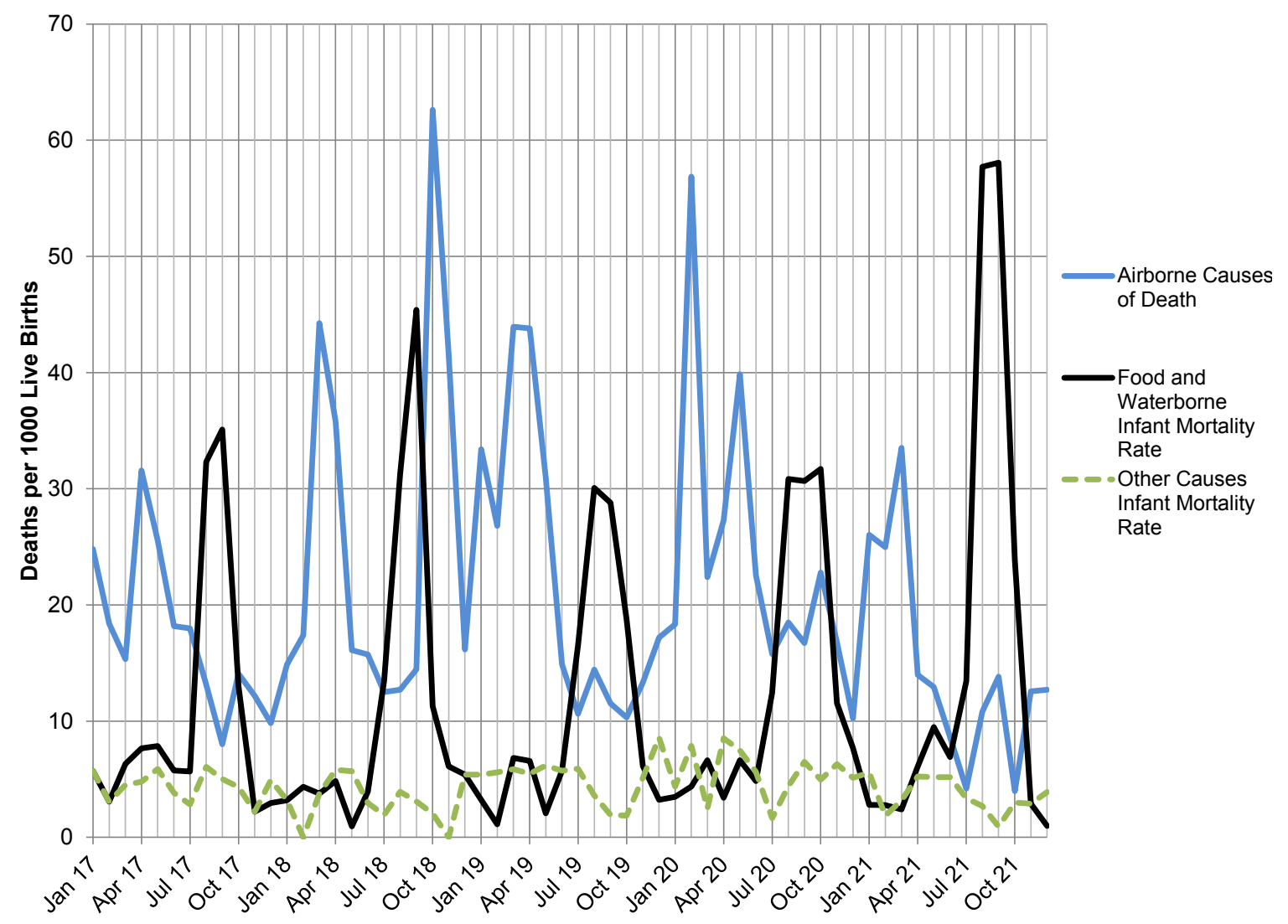

Figure 3. Infectious causes of death, 1917-21: airborne, food and waterborne, and other infectious causes of death.

Except for the second wave of the influenza epidemic of October-November 1918, the increases in deaths from airborne diseases occurred in the winter and spring of each year, between February and May. The monthly variation in the airborne infectious disease rate was significant ( $\mathrm{p}=.04)$. October to November 1918 stands out for three reasons: (1) the increase in deaths from airborne infectious diseases was counter to the usual seasonal pattern of disease distribution (occurring in autumn as opposed to winter/spring); (2) the rate of death was highest for the five year period; and (3) it followed immediately after a particularly severe season of infant deaths from food and waterborne diseases.

Only at two points during the five-year study period were influenza deaths elevated: ${ }^{7}$ October to April 1918-19, and February 1920. The average infant influenza death rate for the five-year period was 2.32 deaths per 1,000 live births ( $\mathrm{n}=141)$, with thirty-three out of the sixty months recording zero deaths from influenza. The death rates from influenza during the second wave of the epidemic period can be seen in Table 6 .

Table 6. Infant death rate from influenza per month, second wave of epidemic.

\begin{tabular}{cc}
\hline Month & $\begin{array}{c}\text { Infant Death Rate From Influenza } \\
\text { (per 1,000 live births) }\end{array}$ \\
\hline September 1918 & $0.00(\mathrm{n}=0)$ \\
October 1918 & $23.61(\mathrm{n}=23)$ \\
November 1918 & $22.00(\mathrm{n}=18)$ \\
December 1918 & $9.70(\mathrm{n}=9)$ \\
January 1919 & $10.78(\mathrm{n}=10)$ \\
February 1919 & $3.34(\mathrm{n}=3)$ \\
March 1919 & $6.84(\mathrm{n}=7)$ \\
April 1919 & $4.38(\mathrm{n}=4)$ \\
\hline
\end{tabular}

7. Including deaths listed as caused by influenza, la grippe, influenzal meningitis, Spanish Influenza, epidemic influenza, and weak from influenza of mother. 
Hallman: An exploration of the effects of pandemic influenza on infant mortality in Toronto, 1917-1921

The influenza death rate for February 1920 was 26.35 deaths per 1,000 live births $(n=30) .{ }^{8}$ The influenza deaths do not account for all the epidemic related deaths, because many deaths were caused by secondary streptococcal and pneumococcal infections (Tashiro et al 1987) and therefore may likely have been recorded as having been due to pneumonia ${ }^{9}$ or bronchitis. This is particularly true if infants with influenza present with different symptoms than adults (Munoz 2003). Further, while there were other airborne diseases that resulted in infant deaths during the study period (tuberculosis, whooping cough, measles, smallpox, chicken pox, diphtheria, German measles, scarlet fever, and typhoid fever), these diseases did not have high death rates, and most infants died from pneumonias. For these reasons, an analysis at the level of airborne diseases is sufficient to explain this epidemic.

\section{Discussion}

The 1918 influenza epidemic affected infant mortality rates in some ways, but many patterns remained unchanged. The overall infant mortality rate did not change significantly and this lack of variation is not without precedent. In the United States, Noymer and Garenne found that "at the youngest ages, influenza death rates in 1918 are about the same as in 1917" (2000: 567). In Ontario "the lack of any great excess in mortality in this age group in 1918 [...] may be noted as contrasted with other groups" (McKinnon 1945: 288). However, although Toronto has been discussed in the larger Canadian context of the influenza epidemic (Pettigrew 1983; MacDougall 1990, 2007; Miller 2002), in terms of World War I (Miller 2002), and the social conditions of the working class (Piva 1979), there has yet to be a comprehensive analysis of the mortality rates and effects of the pandemic on the city. Although many studies mention the infant mortality rate from influenza, there are no studies based directly on infant death records for comparison to the results of this project. The findings from this research, based on the death registrations in Toronto, support the evidence of McKinnon (1945) and Noymer and Garenne (2000), but further studies of infant mortality are needed to discover if this result is the same for infants throughout the world. The reasons that the infant mortality rate remained stable in Toronto are still unknown.

Some researchers argue that adults were at greater risk because some aspect of the virus triggered an overactive response by the immune system "causing excessive infiltration of the tissues by immune cells, resulting in tissue destruction" (Loo and Gale 2007: 267). As the immune system is more mature and experienced in adults, this may explain why adults were at higher risk and infants appeared to be protected. Also, the hypothesis of Noymer and Garenne that "those with tuberculosis (TB) in 1918 were more likely than others to die from influenza" (2000: 565) and that TB incidence was higher among young adult males (2000: 574), may again reveal why infants were relatively untouched. Maternal antibodies may have helped to protect those infants still nursing when the epidemic hit, explaining the predominance of deaths among older infants in this study who may have been undergoing the weaning process.

The apparent stability of the infant mortality rate in Toronto masks certain effects of the 1918 epidemic on infants. There was an unexpected reversal in the sex ratio at death for October 1918. This is important because males are known to be at a disadvantage over females generally, but especially in terms of respiratory diseases (Drevenstedt et al. 2008). The Toronto pattern for 1918 also differs from that for Canada for the period 1921 to 1925, where male deaths from influenza were 133\% greater than for females (MacPhail 1927: 480). Male deaths increased in September 1918, while the female death rate did not increase until October 1918. Generally, the infant mortality rate increases in September due to deaths from food and waterborne diseases, of which males are affected more than females. However, 1918 was unusual in that the harsh food- and waterborne season was followed directly by the epidemic of influenza. Perhaps interplay between these two disease clusters contributed to the reversal in the sex-ratio in October.

In this regard, it is possible that the lowered male-to-female sex ratio at death was due to an underreporting of male deaths during the epidemic, or to preferential care given to male infants when ill. However, there is little evidence to suggest that male infants in Toronto were given better care or were fed differently from females, and there is also no reason to believe that male infants were selectively underreported where females were not.

The 1918 influenza epidemic occurred at a time of year when airborne infectious diseases were generally low. Further, the deaths from food and waterborne illnesses during the late summer and early autumn of 1918 were the

8. The Monthly Reports state that there was another influenza epidemic in February 1920, which began January 19th (Toronto Archives, Fonds 200, Series 365, File 23).

9. For this study, pneumonia deaths include deaths listed as caused by pneumonia, broncho-pneumonia, lobar-pneumonia, and double pneumonia. 
second-highest over the five year period, and greater than the average of the five years combined. This may have been related to the extremes of weather found during August and September 1918 (Environment Canada 2008). ${ }^{10}$ The infants who were at greatest risk from diarrheal deaths were those in the weaning process, who were consuming water or milk directly, in bottle-based foods, or exposed to contaminated water or milk through incomplete sterilization of the bottles. Infants who survive summer diarrheal diseases can be malnourished and immunologically weakened, leading to easier infection with other diseases (Guerrant et al. 1992). This suggests a syndemic relationship between diarrheal diseases, influenza, and the physical environment including weather extremes and social practices regarding transitional feeding. It is likely that the reversed sex ratio of death in October reflected the effect of diarrheal diseases in September: the weakest postneonatal infants had already died and malnutrition altered the profile of babies normally susceptible to airborne diseases. Those infants previously at risk from diarrheal diseases may have been the same infants who were later at risk from influenza.

Discovering who was at risk of infection from food and waterborne illness may help to determine who was at risk from influenza. Diarrheal deaths are directly subject to the quality of water, access to sewer systems, and prior malnutrition (Guerrant et al. 1992, Redlinger et al. 2002). Adequate plumbing could be found in some areas throughout Toronto in 1918 but was particularly insufficient in the slums (Piva 1979); this may be an underlying factor in the variation in infant mortality rates. Influenza was also known to have affected lower socioeconomic classes at a greater rate and intensity than higher classes (The Globe 1918c; Sydenstricker 1931), but somehow had little effect on infant mortality rate in Toronto; it may be that those infants who were weak, malnourished, or socioeconomically disadvantaged were those more likely to die under normal circumstances, and were also those at risk from death during an epidemic. Further research should plot the address of death of the infant located in the death records using Geographic Information Systems technology (GIS) to discover if infant mortality from influenza in 1918 clustered in the impoverished areas of Toronto. This is a necessary component which must be understood: As Herring concludes, "the constellation of biosocial conditions that contributed to this diversity [in global mortality rates] has barely been explored and warrants close scrutiny as the implications are important for future pandemics" (2009: 88).

As stated previously, in order to gain a comprehensive understanding of precisely who was at greatest risk from the $1918 \mathrm{flu}$, it is important to conduct further research on many areas suggested by this paper. Infant mortality did not increase in the city of Toronto because of the influenza epidemic, yet it is unlikely that those infants who died were at equal risk of dying compared to those who did not. Young adults, the care-givers of those infants, were dying in greatly increased numbers. Even when infants did not die, they were certainly affected by the loss of parents and the cultural upheaval in the face of an ending global war, changes in social structure and social welfare systems, and the constant threat of disease resurgence. An analysis of the timing of infant death in comparison to the death of a parent may help to determine the influence of these social stressors on mortality risk. The 1918 influenza epidemic hit Toronto after four years of struggle to constantly save, contribute to the war effort, and survive on dwindling food and fuel resources while the cost of living was steadily increasing. Toronto society was heavily stratified, as people with poor health, sanitation, and nutrition were to be found as well as those with great wealth. Although it was necessary to first establish infant mortality rates to determine what happened to infants, why these patterns occurred is still unknown.

Even though a community may be greatly strained by an epidemic and stressful social conditions, the infant mortality rate is not always a direct reflection of these social disruptions. Infant mortality has been shown to be an important indicator of social health, such that when a community is under stress from nutritional or water insufficiency, social inequalities and unequal access to resources, or endemic disease, infant mortality is generally higher (Moffat and Herring 1999, Galley and Shelton 2001). As this research has shown, infant deaths do not necessarily increase during periods of epidemic stress. Infant mortality may be more of a specific measure of the long-term effects of social strain wearing down the defences of the most vulnerable rather than a comprehensive universal indicator of social disruption. For all of the reasons discussed, infants can be protected during an epidemic, masking a period of undeniable social stress. That the influenza epidemic struck adults in Toronto is not in doubt. What needs to be understood is what mechanisms prevented this epidemic from killing more infants and how that can be translated to prevent deaths in future pandemics.

10. August 1918 recorded both the highest peak temperature as well as the highest mean temperature of any August in the five year study period. September 1918 "was the coldest and wettest month that the city has experienced in 79 years" (The Globe 1918b: 8; Environment Canada 2008). 


\section{Acknowledgements}

This paper was presented at the XXVI IUSSP International Population Conference in Marrakesh, Morocco, on October 2nd, 2009. It was based on my MA thesis, completed at McMaster University in August 2009, under the supervision of Dr. D. Ann Herring in the department of Anthropology. I would like to thank Dr. Herring and Dr. David Earn for access to their data as well as Dr. Alain Gagnon at the University of Western Ontario for his comments and suggestions. I gratefully acknowledge the City of Toronto Archives and the Archives of Ontario, both in Toronto, for access to historical records as well as assistance in this research, as well as the Social Science and Humanities Research Council of Canada for funding to complete this research.

\section{References}

Boucher, S. 1918. The epidemic of influenza. The Canadian Medical Association Journal 8(12):1087-1092.

Bouckaert, A. 1989. Crisis mortality: Extinction and near-extinction of human populations, in Differential Mortality: Methodological Issues and Biosocial Factors, edited by L. Ruzicka, G. Wunsch, and P. Kane. Oxford: Clarendon Press, pp. 217-230.

Toronto Archives. 1917. Monthly Report of the Department of Public Health of the City of Toronto. Archived Material, City of Toronto Archives, Toronto, Ontario. Second Floor Stacks: Fonds 200, Series 365, Folio 3, Box 225022, File 20.

.1918-24. Monthly Report of the Department of Public Health of the City of Toronto. Archived Material, City of Toronto Archives, Toronto, Ontario. Second Floor Stacks: Fonds 200, Series 365, Folio 3, Box 225022, File 21-27.

Collier, R. 1974. The Plague of the Spanish Lady: The Influenza Pandemic of 1918-1919. London: MacMillan.

Collins, S.D., and J. Lehmann. 1951. Trends and epidemics of influenza and pneumonia, 1918-1951. Public Health Reports (1896-1970) 66(46):1487-1516.

CMAJ. 1918. Editorial: The Present Epidemic. The Canadian Medical Association Journal 8(11):1028-1030.

Crosby, A.W., Jr. 1976. Epidemic and Peace, 1918. Westport, Connecticut: Greenwood Press. 1989. America's Forgotten Pandemic: The Influenza of 1918. New York: Cambridge University Press.

Drevenstedt, G.L., E.M. Crimmins, S. Vasunilashorn, and C.E. Finch. 2008. The rise and fall of excess male infant mortality. Proceedings of the National Academy of Sciences 105(13):5016-5021.

Environment Canada. 2008. National Climate Data and Information Archive. Electronic Document, http://www. climate.weatheroffice.ec.gc.ca/climateData/canada_e.html (retrieved February 26, 2009).

Galley, C., and N. Shelton. 2001. Bridging the gap: Determining long-term changes in infant mortality in preregistration England and Wales. Population Studies 55:65-77.

García-Sastre, A., and R.J. Whitley. 2006. Lessons learned from reconstructing the 1918 influenza pandemic. Journal of Infectious Diseases 194:S127-S132.

The Globe. 1918a. Civilians get Spanish "Flu”. The Globe, October 3:6.

-1918b. Not getting any worse. The Globe, October 5:8

. 1918c. Epidemic is not abating. The Globe, October 14:8.

- 1918d. Toronto has best record. The Globe, November 15:9.

. 1918e. No epidemic in Toronto. The Globe, December 30:8.

Gray, A. 1997. Infant Mortality in Mid-Nineteenth Century Southern Ontario: Dundas and Stamford Townships. Master's Thesis. Dept. of Anthropology, McMaster University. 
Guerrant, R.L., J.B. Schorling, J.F. McAuliffe, and M.A. De Souza. 1992. Diarrhea as a cause and an effect of malnutrition: Diarrhea prevents catch-up growth and malnutrition increases diarrhea frequency and duration. American Journal of Tropical Medicine and Hygiene 47(1):28-35.

Handwerker, W.P. 1990. Demography, in Medical Anthropology: Contemporary Theory and Method, edited by T.M. Johnson and C.F. Sargent. New York: Praeger, pp. 319-347.

Harder, T. 1918. Some observations on the more severe cases of influenza occurring during the present epidemic. The Lancet (December 28):871-873.

Hare, R. 1937. Recent advances in the study of influenza. Canadian Public Health Journal 28(4):157-165.

Herring, D.A. 1993. "There were young people and old people and babies dying every week": The 1918-1919 influenza pandemic at Norway House. Ethnohistory 41(1):73-105.

2009. Viral panic, vulnerability, and the next pandemic, in Health, Risk, and Adversity, edited by C. PanterBrick and A. Fuentes. Oxford: Berghan Press, pp. 78-97.

Herring, D.A. (ed.). 2005. Anatomy of a Pandemic: The 1918 Influenza in Hamilton. Hamilton: Allegra Print and Imaging.

Herring, D.A., and L. Sattenspiel. 2007. Social contexts, syndemics, and infectious disease in northern aboriginal populations. American Journal of Human Biology 19(2):190-202.

Hospital for Sick Children. 1919. 44th Annual Report. The Hospital for Sick Children, 67 College Street Toronto. Archived Material, University of Toronto, www.archive.org/details/44reporthospital00hospuoft.

Johnson, N.P.A.S. 2003. The overshadowed killer: Influenza in Britain in 1918-1919, in The Spanish Influenza Pandemic of 1918-19: New Perspectives, edited by H. Phillips and D. Killingray. New York: Routledge, pp. 132-155.

Jones, E.W. 2005. "Co-operation in all human endeavour": Quarantine and immigrant disease vectors in the 1918-1919 influenza pandemic in Winnipeg. Canadian Bulletin of Medical History 22(1):57-82.

- 2007. Influenza 1918: Disease, Death, and Struggle in Winnipeg. Toronto: University of Toronto Press.

Knodel, J.E. 1988. Demographic Behavior in the Past: A Study of Fourteen German Village Populations in the Eighteenth and Nineteenth Centuries. New York: Cambridge University Press.

Lancet. 1918. The Influenza Epidemic. Lancet 2966(November 6, 1918):595-596.

Legislative Assembly of Ontario. 1918-1922. Report Relating to the Registration of Births, Marriages, and Deaths in the Province of Ontario, for the year ending 31st December, 1917-1921 (being the 48th-52nd Annual Reports). Toronto: A.T. Wilgress, Printer to the King's Most Excellent Majesty. Archived Material, Archives of Ontario, Toronto, Ontario. MS B97, Reel 154, 159, 164, 169, 173.

Lofgren, E., N.H. Fefferman, Y.N. Naumov, J. Gorski, and E.N. Naumova. 2007. Influenza seasonality: Underlying causes and modeling theories. Journal of Virology 81(11):5429-5436.

Loo, Y.-M., and M. Gale, Jr. 2007. Fatal immunity and the 1918 virus. Nature 445(18):267-268.

MacDougall, H. 1990. Activists and Advocates: Toronto's Health Department, 1883-1983. Toronto: Dundurn Press. - 2007. Toronto's Health Department in action: Influenza in 1918 and SARS in 2003. Journal of the History of Medicine and Allied Sciences 61(1):56-89.

MacPhail, E.S. 1927. Infant mortality as shown by Canadian vital statistics. American Journal of Public Health 17(5):476-484.

Mathews, T.J., and B.E. Hamilton. 2005. Trend analysis of the sex ratio at birth in the United States. National Vital Statistics Reports 53(20):1-20.

Matteson, D.W., J.A. Burr, and J.R. Marshall. 1998. Infant mortality: A multi-level analysis of individual and community risk factors. Social Science and Medicine 47(11):1841-1854. 
Hallman: An exploration of the effects of pandemic influenza on infant mortality in Toronto, 1917-1921

Mausner, J., and A. Bahn. 1974. Epidemiology: An Introductory Text. Toronto: W.B. Saunders Company.

McCullough, J.W.S. 1918. The control of influenza in Ontario. Canadian Medical Association Journal 8(12):1084-1085.

McKeown, T. 1976. The Modern Rise of Population. New York: Academic Press.

McKinnon, N.E. 1945. Mortality reductions in Ontario, 1900-1942. II. Canadian Journal of Public Health 36(7):285298.

Mercier, M.E. 2006. The social geography of childhood mortality, Toronto, 1901. Urban Geography 27(2)126-151.

Miller, I.H.M. 2002. Our Glory and Our Grief: Torontonians and the Great War. Toronto: University of Toronto Press.

Moffat, T. 1992. Infant Mortality in an Aboriginal Community: An Historical and Biocultural Analysis. Master's Thesis. Dept. of Anthropology, McMaster University.

Moffat, T., and D.A. Herring. 1999. The historical roots of high rates of infant death in aboriginal communities in Canada in the early twentieth century: The case of Fisher River, Manitoba. Social Science and Medicine 48:18211832 .

Morsy, S. 1990. Political economy in medical anthropology, in Medical Anthropology: Contemporary Theory and Method, edited by T.M. Johnson and C.F. Sargent. New York: Praeger, pp. 26-46.

Munoz, F.M. 2003. Influenza virus infection in infancy and early childhood. Paediatric Respiratory Reviews 4:99-104.

Noymer, A., and M. Garenne. 2000. The 1918 influenza epidemic's effects on sex differentials in mortality in the United States. Population and Development Review 26(3):565-581.

Oertel, H. 1919. Anatomical and bacteriological findings in the recent epidemic pneumonia. Canadian Medical Association Journal 9(4):339-344.

Ontario Death Registrations. 1917-1921. Archived Material, Archives of Ontario, Toronto, Ontario. MS 935, Reels 228-229, 238-240, 251-252, 261-262, 273-274.

Oxford, J.S., A. Sefton, R. Jackson, W. Innes, R.S. Daniels, and N.P.A.S. Johnson. 2002. World War 1 may have allowed the emergence of "Spanish" influenza. The Lancet Infectious Diseases 2:111-114.

Padiak, J. 2004. Integration of specificity variation in cause-of-death analysis. Historical Methods 37(1):39-44.

Pettigrew, E. 1983. The Silent Enemy: Canada and the Deadly Flu of 1918. Saskatoon: Western Producer Prairie Books.

Piva, M.J. 1979. The Condition of the Working Class in Ontario, 1900-1921. Ottawa: University of Ottawa Press.

Redlinger, T., V. Corella-Barud, J. Graham, A. Galindo, R. Avitia, and V. Cardenas. 2002.Hyperendemic Cryptosporidium and Giardia in households lacking municipal sewer and water on the United States-Mexico border. The American Journal of Tropical Medicine and Hygiene 66(6):794-798.

Robertson, E.A. 1919. Clinical notes on the influenza epidemic occurring in the Quebec Garrison. The Canadian Medical Association Journal 9(2):155-159.

Rosenberg, C.E. 1989. Disease in history: Frames and framers. The Milbank Quarterly 67(suppl. 1):1-15.

Sattenspiel, L., and D.A. Herring. 1998. Structured epidemic models and the spread of influenza in the Central Canadian Subarctic. Human Biology 70(1):91-115.

- 2003. Simulating the effect of quarantine on the spread of the 1918-19 flu in Central Canada. Bulletin of Mathematical Biology 65(1):1-26.

Scheper-Hughes, N. 1997. Demography without numbers, in Anthropological Demography: Toward a New Synthesis, edited by D.I. Kertzer and T. Fricke. Chicago: University of Chicago Press, pp. 201-222.

Solomon, L. 2007. Toronto Sprawls: A History. Toronto: University of Toronto Press 2007.

Sydenstricker, E. 1931. The incidence of influenza among persons of different economic status during the epidemic of 1918. Public Health Reports 46(4):154-170. 
Tashiro, M., P. Ciborowski, H.-D. Klenk, G. Pulverer, and R. Rott. 1987. Role of Staphylococcus protease in the development of influenza pneumonia. Nature 325(5):536-537.

Taubenberger, J. 2003. Genetic characterisation of the 1918 'Spanish' influenza virus, in The Spanish Influenza Pandemic of 1918-1919: New Perspectives, edited by H. Phillips and D. Killingray. New York: Routledge, pp. 39-46.

Taubenberger, J., A. Reid, and T. Fanning. 2000. The 1918 influenza virus: A killer comes into view. Virology 24:241-245.

Thomas, M.K., D.F. Charron, D. Waltner-Toews, C. Schuster, A.R. Maarouf, and J.D. Holt. 2006. A role of high impact weather events in waterborne disease outbreaks in Canada, 1975-2001. International Journal of Environmental Health Research 16(3):167-180.

Williams, N., and C. Galley. 1995. Urban-rural differentials in infant mortality in Victorian England. Population Studies 49(3):401-420.

Winternitz, M.C., I. Watson, and F. McNamara. 1920. The Pathology of Influenæa. New Haven: Yale University Press.

World Health Organization. 2007. International Statistical Classification of Diseases and Related Health Problems. 10th Revision Version for 2007.

Young, G.S. 1919. The recent epidemic of pneumonia: Bedside findings and some inferences. Canadian Medical Association Journal 9(5):421-426. 